\title{
Revista de Medicina: a publication on the updating of medical thinking, 1916-2016
}

\author{
Cyro Festa Neto ${ }^{1}$, André Mota ${ }^{2}$
}

$\mathrm{W}$ hen we study the first medical journals produced in Brazil in the Nineteenth Century, we locate much of this production covering topics that could be of interest to a general public in a sense of acquiring readers and, of course, specific subscribers:

The election of hygiene as a dialogue field between medicine and society and a privileged field of scientific production enables our understanding not only of how certain diseases were raised to the status of problems of social relevance, but also of how the implementation of the debate on the health problems of the country happened (p.331)

With the arrival of the Republic in 1889 and the impulses of an elite that sought "civilization and progress", the press was amplified, discovering "multiple technological innovation processes", which allowed for the use of various types of illustration - cartoons, photographs - as well as the increase in printings, better printing quality, lower printing costs, providing a sort of early stage of mass communication" (p.83)2. In this context, as the medicine and health institutionalization process in São Paulo was deepened, its editorial production in the medical-scientific field occurred simultaneously:

At first we continuously found names of the most important physicians who were active at that time: Luiz Pereira Barreto, Adolfo Lutz, Emílio Ribas,

\begin{abstract}
Arnaldo Vieira de Carvalho, Vital Brazil, Rubião Meira. Afterwards we could find medical articles written by physicians such as Lemos Torres, Jairo Ramos, Afrânio do Amaral, Antonio Carlos Pacheco e Silva, all of them personas with privileged access to publishing in daily newspapers and specialized journals (p.99) ${ }^{3}$.
\end{abstract}

It is in this context that we can understand the dimension that Revista de Medicina (RM) has gained since its devising. Even though it is a student journal of São Paulo Faculty of Medicine and Surgery, much has been published by Professors and students as well as national and international physicians, in a very interesting and unprecedented approach, in which several objects earned the same speaking space, conforming scientific, corporate and institutional proposals.

\section{Revista de Medicina: the first institutional applications ${ }^{4}$}

It was amidst such turmoil that Oswaldo Cruz Academic Center (Centro Acadêmico Oswaldo Cruz - CAOC) launched its Revista de Medicina (Journal of Medicine) (RM) in July 1916, featuring on its first pages the words of Physiology professor Ovidio Pires de Campos, with an article that alluded to the importance of transferring the Academic Center to the responsibility of those who would support and help building the name of the

1. Full Professor from the Dermatology Department of University of São Paulo School of Medicine.

2. Professor in the Preventive Medicine Department of University of São Paulo School of Medicine; Historian and Coordinator of FMUSP's Prof. Carlos da Silva Lacaz History Museum. E-mail: amota@museu.fm.usp.br

Mailing address: André Mota Av. Dr. Arnaldo, 455, $4^{\text {th }}$ floor. Cerqueira Cesar. 01246-903 - São Paulo, SP, Brazil. 
Faculty of Medicine. So, $R M$ was born with the following responsibility:

There is much to be praised in this beautiful project of its executives who, thus and yet once, provided obvious evidence of how sharp and clearly they could understand, read and make effective the true intentions of the Councilto whose superintendence they lend much of the their effort and their activity, and their natural passion - preventing the 'Center' from sliding from the high scientific cogitations and crashing, and come to be flatten in the unfruitful shoals of personal struggles and competitions. The first fruits of having founded and solidly established, through its tribune, the highly meritorious work of popularizing the good doctrines and disseminating among its members those of the principles that should guide them and to which one should connect in the exercise of his/her future profession was not enough to the 'Center': it wanted to go further, deciding, with rare accuracy, that, in the pages of this magazine, this same work - so auspiciously carried out - would be continued, broader and more intense, and perpetuated, leveling professors and students in complete and perfect communion of ideals (p.3-4) .

Through this framework, the "nature" of the magazine begins to acquire its first constitutive features. One of them was the search for resources for making the Banner in 1916, through contributions in the so called Golden Book (Livro de Ouro), aiming at the accession by students and teachers:

The painting works for the banner must be delivered to the distinguished painter Mr. Oscar Pereira da Silva; the carpentry works must be delivered to the School of Arts and Crafts and the sculpture works, to the well-known Mr. Julio Starace, who has offered to do this work for free. As the Center's Banner was the same as the Faculty of Medicine's, the board submitted the project to the Congregation for approval, which named doctors Ovídio Pires de Campos, Guilherme B. Milward and Adolpho Lindemberg to give their opinion (p.53)

After some months the Faculty's Banner was ready, composed as follows:

(...) Oscar Pereira da Silva, an inspired painter from São Paulo, traced the panel in which he made the figure of Hygieia walking towards the foreground not yet achieved, with laurels covering the path, the dominant element in the composition. The background of the composition is occupied by the Sun that illuminates the Temple of Aesculapius, and the path that reaches outside of it. The temple, in the form of a pediment and Doric columns, stands in Epidaurus, near the ocean, where the first signs of animal life recorded by science occurred. Along the road walked by Hygieia there are the symbolic reproductions of Hippocrates, Galen and Bichat, the great medicine geniuses, the latter for his treaty on general Anatomy, published a year before his death in 1801 (...) therefore, both ancient and contemporary history were represented (p.24)

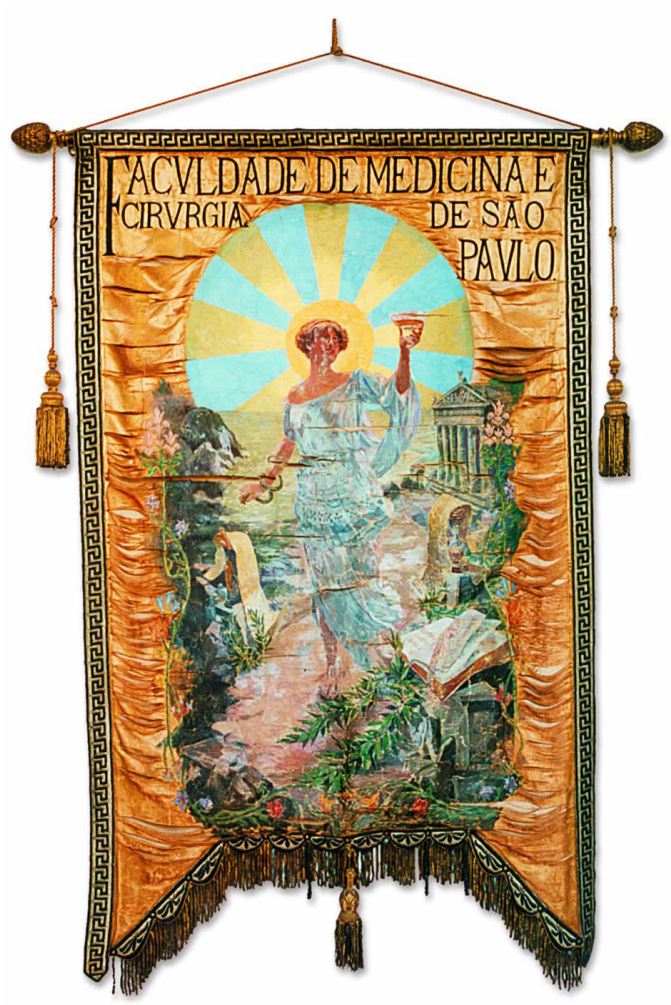

Figure 1. Banner of the São Paulo Faculty of Medicine and Surgery, 1918

Another important moment occurred with the records regarding Arnaldo Vieira de Carvalho's sudden death on June 6,1920 . In $R M$, the day of his passing figured as a milestone in the history of the entire city of São Paulo. The funeral procession, as they said, attracted the people who joined the present medical class. Ahead, the banner would represent the esteem and harmony prevailing throughout the institution. In a student's speech, the votes were for the Faculty to continue with deeds that mirrored the successes of a journey which had already begun and the fruits of this tradition. He compared the school to

(...)a large and lush jungle tree, with strong and intertwined branches. Age has already given development to the roots, now deep and embracing a generous and fertile land portion; its leafy branches stretch, seeking the blue, limitless space; the trunk has already withstood the mercilessness of many Winters (...) may this great tree never lose its leaves: the traditions that it already represents, even though it is young (p.77) ${ }^{8}$. 


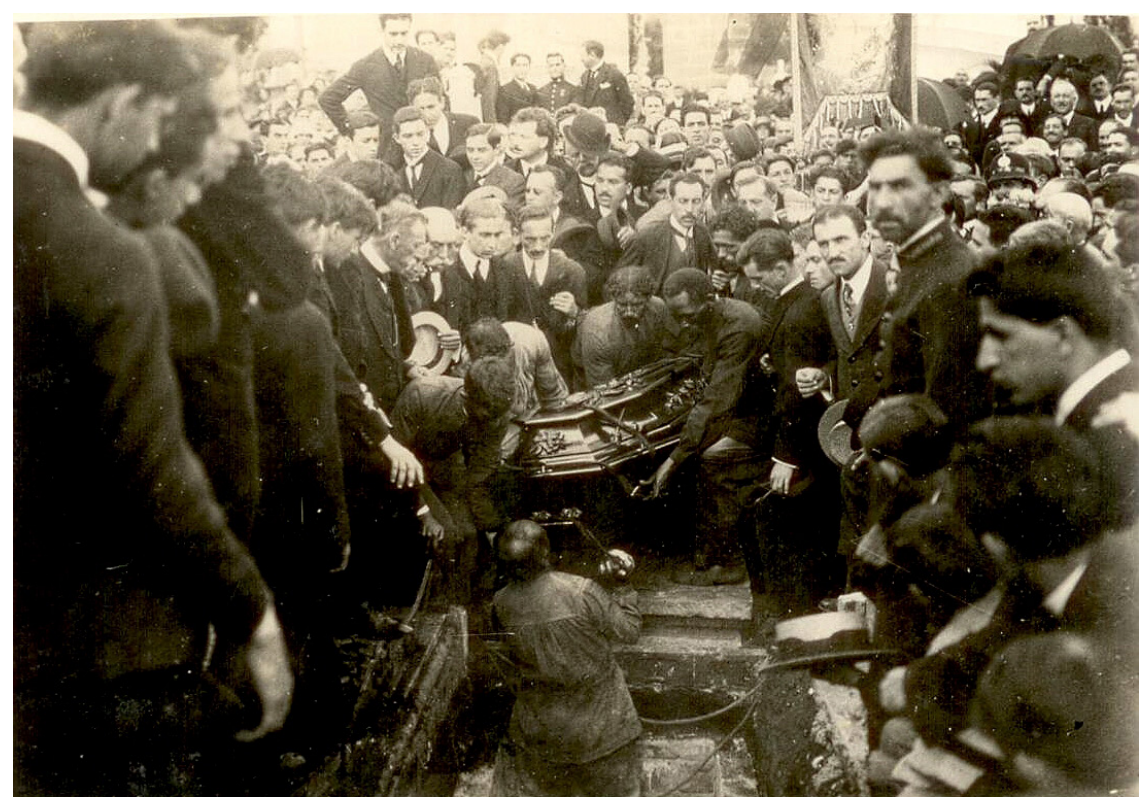

Figure 2. Arnaldo Vieira de Carvalho's funeral, 1920

The 1930s may represent one of the most transforming periods for the Faculty of Medicine and the lives of those who attended it. The absence of Dr. Arnaldo and the interventions of the Rockefeller Foundation brought the restructuring of academic life quickly. New buildings, a new curriculum and the incorporation of the Faculty to the Universidade de São Paulo are some relevant points. However, it was the Civil War in 1932 and the massive presence of the Faculty of Medicine in its health trains that left the most surprising records. Regarding the students, the death of José Greff Borba, a student who had an accident

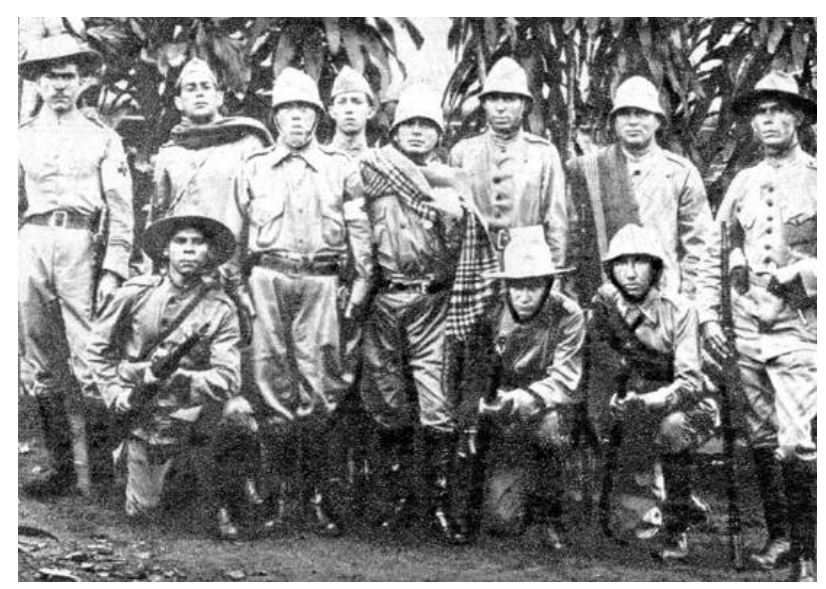

Figure 3. Physicians from São Paulo next to Julio de Mesquita, 1932 while making bombs and grenades at the Polytechnic School, shocked everyone. And it was $R M$ that registered publicly the feeling of that moment:

1932 - Mourning! Many felt in their soul a renewed sense of disenchantment of living. The hearts, already wounded badly by many sorrows and painful prospects, suffered. Little, however, because the enthusiasm and patriotic ardor would overcome all pain and sorrow. But for us, students of the Faculty of Medicine, fate reserved a misfortune. Before this we could not place any feeling able to undermine our reasons for intense grief; this misfortune was Borba's death (p.201) .

However, one fact remained in the Faculty's hallway conversations and concerned the need to terminate the contract signed with the Rockefeller Foundation, after all, if it invested one million dollars in the construction of the buildings and their structure, between 1928-1931, the part of São Paulo Government in the construction of a teaching hospital, Hospital das Clínicas (Clinical Hospital), was left to be paid. The pullback of Vargas government before this need attested the tense situation of those years. However, it will be the students and professors united, from 1937 on, the ones to rekindle the flame of that institutional need, having positive results when the Central Institute would begin to be built in 1938 . The $R M$ released its "Chronica", adressing with the following subject:

São Paulo needs the Clinical Hospital. In a few words, here is a truth we all feel. We said, and quite rightly, we 
feel it, because from the medical student, who is starting his or her life in the hospital, to Professors and Assistants, all of us have our field of action limited and our work capacity reduced due to the lack of a hospital suitable for our activities, comparable to the land of Piratininga. Besides that, the number of beds for the patients is too small, mainly for the free hospital care. Throughout the State the beds for patients are in the ratio of 1 to 1,000 inhabitants. But we are sure that, within a short period time, the Clinical Hospital will be a reality, because as prof. Flamínio Fávero rightly said, 'We have a serious word of honor towards the [Rockefeller] Foundation who gave us the current building for the laboratories: that the clinics would also have their facilities'. The word of São Paulo cannot fail, because it would be the first time. The recent donation of the State Government in the amount of 5,000 contos (Brazilian currency at the time) to start building the hospital confirms the words above, a fact that makes all of us very proud (p.49) ${ }^{10}$.

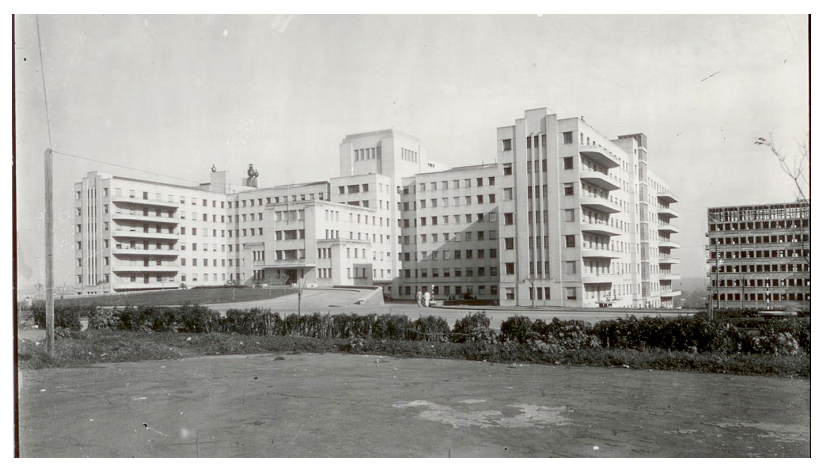

Figure 4. Hospital das Clínicas (Clinical Hospital)-FMUSP, 1944

If records of USP Faculty of Medicine history can be found among the pages of $R M$, another founding nature was of immense importance in the life of this editorial production. This is because the results of research and developed technologies, fruits of the immersion of Professors, Physicians and students in their laboratories and offices will be largely presented through scientific papers, reports and comments, revealing that "the scientific adjective is not assigned to isolated texts which are able to oppose to the opinion of the crowds due to some mysterious faculty. A document becomes scientific when it intends to stop being something isolated and when people engaged in its publication are many and are explicitly indicated in the text. Those reading it are the ones who become isolated" (p.58) $)^{11}$.

\section{A journal about the updates on medical knowledge}

Until the emergence of the Hospital das Clínicas
(1944) and its institutes, when a series of periodic publications and medical and scientific journals was produced, it was $R M$ that disclosed such matters. From the medical corporate changes to the specialties that were taking form, themes and names start being submitted, leaving the marks and fundamental efforts to make the Faculty Medicine earn, years later, a place among the best medical schools in the World.

Table 1. Themes and authors of papers published in the 1938 issue

\section{Revista de Medicina, n.79, v.24, 1938}

Efficienza sportiva e doping... Prof. Carlos Foá

Pleuriz cholesterinico tuberculoso... Prof. Antonio de Almeida Prado

Acerca do problema psicológico das tendências... (Regarding the psychological problem of the tendencies...) Prof. Cunha Lopes

Persistencia da veia cava superior esquerda... (Persistence of left superior vena cava...) Dr. Alvaro Pontes

Uréa e função renal... (Urea and renal function) Dr. Nevio Pimenta

Sobre um caso de reticulohistrocitoma generalizado dos gânglios lymphaticos... (On a case of generalized reticulohistiocytoma of the lymphatic ganglia...) PhD Candidate Lamartine Assis

Table 2. Themes and authors of papers published in the 1940 issue

\section{Revista de Medicina, n.79, v.24, 1940}

A Revista de Medicina nas palavras do Prof. (Revista de Medicina in the words of Prof.) Rubião Meira

Liga de Combate ao Câncer (Fight Against Cancer League) ... Prof. Jayme Regalo

Sorodiagnostico do Câncer... (Cancer Serum Diagnosis) Prof. Jayme Regalo

Las antihormonas... Dr. Gonzales Torres

Retite estenosante de natureza linfogranulomatosa... (Stenosing rectitis of lymphogranulomatotic nature) Dr. Arouche Toledo e Doutorando Carlos da Silva Lacaz

Conceito de infecção em cirurgia... (Concept of infection in surgery...) Dr. Ary de Siqueira

Espondilartrite anquilosante... (Ankylosing spondyloarthritis...) PhD Candidate João Raphael Libonati

Currently, $R M$, in addition to its historical importance, maintains its responsibility to update and renew medical thought. Through its dossiers we can understand the capacity of the publishing to pluralize the debate from the most varied subjects, contributing to a wide insight into the medical field and its practice. As an example, in 2009 the magazine proposed a special issue on "Transplants", in 2012 a relevant discussion of the 
"Medical Specialties" and in 2013 an edition focusing only on "Health Promotion".

These are some of the many topics addressed, all written by researchers and professors with vast knowledge in their field and expertise. In this aspect, which is an inner aspect of field research, the diversity and magnitude of the published studies grant to the $R M$ a huge responsibility because it indicates the paths of medical science in Brazil and abroad. We mention some themes, such as "laser as a dermatology's ally" from 2007, an interesting article from 2011 on "transcranial stimulation" and in 2014 a study focusing on "medical education supported by the

\section{REFERENCES}

1. Ferreira LO. Os periódicos médicos e a invenção de uma agenda sanitária para o Brasil (1827-43). Hist Cienc Saúde - Manguinhos. 1999;6(2):331-51. http://dx.doi.org/10.1590/ S0104-59701999000300006.

2. Eleutério ML. Imprensa a serviço do progresso. In: Martins AL. História da imprensa no Brasil. São Paulo: Contexto; 2008. p.83.

3. Silva MRB. Revistas médicas paulistas e a nova realidade republicana. In: Mota A, Marinho MGSMC, organizadores. Práticas médicas e de saúde nos municípios paulistas: a história e suas interfaces. São Paulo: USP, Faculdade de Medicina, CD.G Casa de Soluções e Editora; 2011. p.89-104. (Coleção Medicina, Saúde e História, 1). Available from: http://www2.fm.usp.br/gdc/docs/museu_78_vol_1.pdf.

4. Mota A. A Revista de Medicina: entre histórias e registros, 1916-1940. Rev Med (São Paulo). 2012;91(supl. esp.):5-12. Disponível em: http://www.revistas.usp.br/revistadc/article/ view/59052/62039.

5. Campos OP. Revista de Medicina (Orgam do Centro Academico Oswaldo Cruz da Faculdade de Medicina e Cirurgia de São Paulo). Rev Med (São Paulo). 1916;1(1):3-4. Available from: http://www.revistas.usp.br/revistadc/article/ view/56465/59536.

6. Mazzieri BR. Símbolos da medicina. São Paulo: Museu Prof. Carlos da Silva Lacaz-FMUSP; 1995. p.24. community: collective intervention projects as a way of learning about networking and intersectoriality".

The task of mapping $R M$ will always be a difficult one due to how long it has been active and the great amount of contributions it has had since then. However it will always be easy to identify it in its innovative character, noticing its marks in each paper and study presented, in each guest author in each issue published. Its presence is already a symbol of success in the history of Brazilian Medicine. May it always persist in this task of bringing closer to its readers that which is for today's Medicine often a dream of many in days of tomorrow.

7. Noticiário. Fala do estudante Felicio Cintra do Prado. Rev Med (São Paulo). 1920;3(16/17):77. Available from: http:// www.revistas.usp.br/revistadc/article/view/56802/59783.

8. Editorial. Rev Med (São Paulo). 1932;16(57):201.

9. Antunes ML. Chronica. Rev Med (São Paulo). 1937;19(63):49. Available from: http://www.revistas.usp.br/revistadc/article/ view/50682/54793.

10. Latour B. Ciência em ação: como seguir cientistas e engenheiros sociedade afora. São Paulo: Unesp; 2000. p.58.

\section{BIBLIOGRAPHY}

Guimarães AP. Arnaldo Vieira de Carvalho: biografia e crítica. São Paulo: FMUSP; 1967.

Marinho MGSMC, Mota A, organizadores. Trajetória da Faculdade de Medicina: aspectos históricos da Casa de Arnaldo. São Paulo: FMUSP/CD.G Casa de Soluções Editora; 2012. v.1-2.

Mota A. Tropeços da medicina bandeirante: medicina paulista de 1892-1920. São Paulo: Edusp; 2005.

Nadai E. Ideologia do progresso e ensino superior (São Paulo 1891-1934). São Paulo: Loyola; 1987.

Schraiber LB. O médico e seu trabalho: limites de liberdade. São Paulo: Hucitec; 1993. 